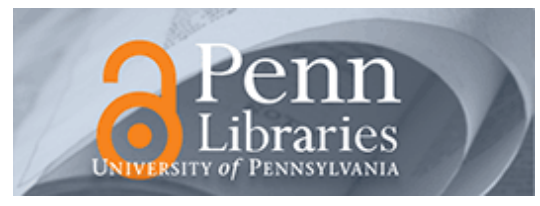

University of Pennsylvania

ScholarlyCommons

Management Papers

Wharton Faculty Research

2010

\title{
Corporations and Economic Inequality Around the World: The Paradox of Hierarchy
}

Gerald F. Davis

J. Adam Cobb

University of Pennsylvania

Follow this and additional works at: https://repository.upenn.edu/mgmt_papers

Part of the Organizational Behavior and Theory Commons

Recommended Citation

Davis, G. F., \& Cobb, J. (2010). Corporations and Economic Inequality Around the World: The Paradox of Hierarchy. Research in Organizational Behavior, 30 35-53. http://dx.doi.org/10.1016/j.riob.2010.08.001

This paper is posted at ScholarlyCommons. https://repository.upenn.edu/mgmt_papers/150

For more information, please contact repository@pobox.upenn.edu. 


\title{
Corporations and Economic Inequality Around the World: The Paradox of Hierarchy
}

\author{
Abstract \\ Using time-series data from the US since 1950 and from 53 countries around the world in 2006, this \\ chapter documents a strong negative relation between an economy's employment concentration (that is, \\ the proportion of the labor force employed by the largest 10, 25, or 50 firms) and its level of income \\ inequality. Within the US, we find that trends in the relative size of the largest employers (up in the 1960s \\ and 1970s, down in the 1980s and 1990s, up in the 2000s) are directly linked to changes in inequality, and \\ that corporate size is a proximal cause of the extravagant increase in social inequality over the past \\ generation. We conclude that organization theory can provide a distinctive contribution to understanding \\ societal outcomes. \\ Disciplines \\ Organizational Behavior and Theory
}




\title{
Corporations and economic inequality around the world: The paradox of hierarchy
}

\author{
Gerald F. Davis \\ Ross School of Business \\ University of Michigan \\ 701 Tappan St. \\ Ann Arbor, MI 48109-1234 \\ (734) 647-4737 \\ gfdavis@umich.edu

\section{J. Adam Cobb} \\ Ross School of Business \\ University of Michigan \\ 701 Tappan St. \\ Ann Arbor, MI 48109-1234 \\ adamcobb@umich.edu
}

To appear in Research in Organizational Behavior

March 31, 2010

We thank Art Brief, Barry Staw, and seminar participants at the University of Michigan for their excellent comments. 


\begin{abstract}
Using time-series data from the US since 1950 and from 53 countries around the world in 2006, this chapter documents a strong negative relation between an economy's employment concentration (that is, the proportion of the labor force employed by the largest 10, 25, or 50 firms) and its level of income inequality. Within the US, we find that trends in the relative size of the largest employers (up in the 1960s and 1970s, down in the 1980s and 1990s, up in the 2000s) are directly linked to changes in inequality, and that corporate size is a proximal cause of the extravagant increase in social inequality over the past generation. We conclude that organization theory can provide a distinctive contribution to understanding societal outcomes.
\end{abstract}


The triumph of shareholder capitalism in the United States over the past generation has corresponded to a dramatic increase in income inequality. The proportion of the nation's income going to the top $1 \%$ of earners has reached levels not seen since the stock market boom of the 1920s (Piketty \& Saez, 2003). No European country-including Russia--surpasses the United States in inequality. Yet social scientists have yet to explain convincingly how this came to be.

One economic explanation for increasing inequality focuses on technologicallydriven changes in the mix of skills required by the economy, which widens the wage gap between those who have these skills (e.g., computer literate college graduates) and those who do not. Similar explanations were offered to explain the rise in inequality during the Second Industrial Revolution in the late 19th century. But cross-national comparisons are inconsistent with this interpretation. France, for instance, has seen no substantial change in inequality since the Second World War (Piketty \& Saez, 2003), and Japan and the Nordic countries—-hardly technological slackers—are among the most equal nations on Earth. Yet in the US, inequality has reached levels most comparable to countries like Thailand and Senegal.

We propose that the most immediate cause of increasing (or decreasing) inequality in advanced economies is aggregate change in corporate organization. More specifically, change in the relative size of the largest organizations in an economy has a direct and —we argue—causal relation to the degree of income inequality. Factors that influence the size of organizations-technology, managerial methods, innovations in organization design, power struggles over the purpose of the corporation-thereby indirectly influence inequality. We present evidence that, both cross-nationally and over 
time within the US, there is a very strong correlation between the level of corporate employment concentration--the proportion of the labor force employed by the 10 or 25 or 100 largest domestic businesses--and income inequality at the societal level. Within the US from 1950 to 2006, this correlation year-to-year was roughly -0.8. That is, the greater the sizes of the largest employers relative to the size of the labor force, the lower the level of economy-wide income inequality. When employment concentration increased during the merger wave of the 1960s, inequality dropped to the lowest levels on record. As corporations shrank due to bust-up takeovers, spinoffs, layoffs, and outsourcing during the 1980s and 1990s, employment concentration declined, while inequality correspondingly increased. The reasons for the merger wave and the the subsequent "demerger” waves are well-known from the literature in organization theory (e.g., Davis, Diekmann, and Tinsley, 1994). At a deeper level, conceptions of what a corporation is and to whom it is responsible shape whether typical corporations in an economy are large or small. But it is this fact—greater or lesser employment concentration-that appears to have a nearly mechanical effect on inequality.

Our findings reveal a paradox. Corporate hierarchies are the defining structures of inequality in modern societies, and earnings inequality is greater in big firms than small firms (Kalleberg \& Vanburen, 1994). Commentators routinely lament the growing gap between the compensation packages of CEOs and the average wages of their workers (e.g. Frank \& Cook, 1995). Yet societies in which employment is more concentrated within large corporations are more equal than those in which employment is dispersed among smaller firms. ${ }^{1}$ In Denmark, the most equal society in our sample, the ten largest

\footnotetext{
${ }^{1}$ Throughout the paper, we use the Gini coefficient as our measure of income inequality at the economywide level, and explain it in more detail later. The Gini coefficient reflects how the aggregate income of a
} 
domestic corporations employ the equivalent of one-quarter of the workforce, and the biggest Danish firm in 2006 had a workforce of over 270,000 (albeit not all employed in Denmark). In Colombia, the most unequal country we study, the largest firms employ less than one-quarter of one percent of the workforce, and the biggest Colombian firm had just 7000 employees, in a country nearly ten times the size of Denmark. The US is at the 70th percentile of inequality among nations, with about $3 \%$ of the workforce employed by the biggest firms--numbers roughly comparable to Russia. Yet in 1969, almost $6 \%$ of the US workforce was employed in the largest firms--just as the US had achieved the lowest level of income inequality in its recorded history.

This "paradox of hierarchy" bears some resemblance to the famous ecological fallacy. Robinson (1950) noted that correlations at the aggregate level need not correspond to correlations at the individual level, and showed that the percentage of a state's population that is literate was positively correlated with its percentage of immigrants, although individual immigrants were less likely to be literate than nonimmigrants. Similarly, although African-Americans voted for Barack Obama at nearunanimous levels in the 2008 presidential election, four of the five states with the highest proportion of African-Americans went for his opponent. Surprising compositional effects are common in organization theory. For instance, March and Simon (1958) showed how smart organizations could be comprised of dumb (boundedly rational) individuals, while DiMaggio and Powell (1983) argued that individually rational organizations could aggregate up into collectively irrational fields. The paradox of

society is divided: $\$ 1$ divided among 100 persons would yield a Gini of 0 (perfect equality), while the same dollar given to only one person would yield a Gini of 1 (perfect inequality). Unlike other measures of dispersion, such as standard deviation, it does not vary with the scale used. Thus, very low-income societies can have very high inequality, and vice versa. Empirically, the Gini declines with average income in an economy - that is, on average richer societies are more equal than poorer societies. 
hierarchy is analagous: unequal organizations aggregate into collectively more equal societies.

In this chapter, we briefly review the literature on economic inequality and the part played by organizations in social stratification. We then review some of the major changes in corporate organization and the employment relation in the US since the end of the Second World War and their implications for employment concentration. Next we present evidence on the link between employment concentration and income inequality among 53 countries, as well as time-series evidence for the US from 1950 to 2006 . We find a remarkably strong relation between the Gini coefficient—a measure of income inequality—and the proportion of the labor force employed by the ten largest domestic businesses. Around the world, clear regional patterns emerge: Nordic countries show both the lowest levels of inequality and high levels of employment concentration; Latin American countries show the highest levels of inequality and the lowest levels of employment concentration; and Western European and Mediterranean countries are largely in between. Former Communist countries (other than Russia and China) form an intriguing off-diagonal, exhibiting both low inequality and relatively low employment concentration. These groupings map onto different "varieties of capitalism” (cf. Amable, 2003), which in turn support divergent conceptions of corporate purpose and organization. We conclude with a somewhat speculative discussion of the sources of this relationship and its implications for future research on the effects of organizational forms on social inequality. Our approach is frankly exploratory: to our knowledge, this is the first paper to examine the correlates of employment concentration. But we believe the results indicate that this may be a rich construct for further investigation. 


\section{Organizations and social inequality}

Explaining social inequality is one of the defining problematics of sociology as a discipline, animating theorists from Marx and Durkheim to Otis Dudley Duncan and Jeffrey Pfeffer. By definition, inequality is a relational term. The unit of analysis for examining inequality can be the group, the organization, the society, or the world economy (e.g. Firebaugh, 1999 examines inequality among national averages). We focus on the societal level--specifically, on inequality within a national economy as the unit of analysis. The extant literature on social inequality is wide and deep, and we can only engage a small segment of it.

Inequality is distinct from poverty. Poverty is a first-order problem, and among low-income countries, policies for alleviating poverty take precedence over questions of inequality. But above a threshold level of economic development, inequality is strongly related to a range of social ills. Among the world's developed economies, inequality is correlated with lower life expectancies, higher rates of infant mortality, higher teenage pregnancy rates, higher rates of homicide and other crime, higher rates of incarceration, and higher rates of mental illness (see Wilkinson \& Pickett, 2009 for a recent summary). The most frequently replicated findings are correlations between inequality and life expectancy at birth, and between inequality and infant mortality. The precise mechanism of causation is controversial. Wilkinson and Pickett (2009) argue for several causal pathways leading from inequality to social evaluation anxiety and stress, and from there to health outcomes. (The link from stress to health outcomes is itself well-documented.) Some studies have found the causal tie between inequality and aggregate health outcomes to be elusive when other factors are taken into account (e.g. Mellor \& Milyo, 2001), and 
high-quality time series data are largely lacking. But even if inequality and other social ills are correlated due to some third factor, it is worth unpacking what that third factor is. ${ }^{2}$

Prior research suggests that social inequality is not a fixed property of an economy but varies over time within countries. Economists have attributed economywide inequality to changes in technology and economic development (e.g. Acemoglu, 2002). The Kuznets Curve famously depicts the relation between economic development and inequality. Economist Simon Kuznets, writing in the mid-1950s, discovered an inverse-U relation between the level of industrialization of an economy and the level of inequality (Kuznets, 1955). Inequality evidently increased with the level of industrialization, but then declined afterwards.

Subsequent works found that the inverse-U relation was not an immutable law of nature, and the years since Kuznets wrote have produced challenges to the simple version of the Kuznets curve (e.g. Alesina \& Rodrik, 1994; Perotti, 1993). In particular, the cross-national regularities Kuznets found did not always hold over time within countries. In the US, inequality dropped substantially during WWII and did not return to pre-War levels for decades. The most equal year on record in the US was 1968. But more recently there has been a vast upsurge in inequality, returning the US to a new Gilded Age- perhaps more of an N-curve than an inverse-U. The implication of these findings is that the source of the potential link between economic development and inequality is

\footnotetext{
${ }^{2}$ Indeed, authors disputing the causal link between inequality and aggregate health outcomes suggest something very similar to what we examine as their "third factor: "...industrial restructuring or other employment shocks may have detrimental effects for individual health outcomes (through the loss of insurance coverage or income), while at the same time increasing income inequality...Given the omission of factors that simultaneously affect inequality and health, it should be no surprise to sometimes observe a significant association between inequality and aggregate health measures, regardless of the sign of that association" (Mellor \& Milyo, 2001, p. 515)
} 
ambiguous. Technology-based changes in required skills are one possibility, but the direct evidence on this is not yet compelling.

\section{Insert Figure 1 about here}

\section{Bureaucracy and social inequality}

A separate literature on stratification in sociology focused on individual-level attainment. The prototypical study would contain a regression in which individual income, or socio-economic status, was modeled as a function of education, sex, race, mother's education, and so on (e.g. Blau \& Duncan, 1967). A compelling critique of this literature pointed out that attainment does not take place strictly at an individual level: organizations are where stratification happens (Baron \& Bielby, 1980; Pfeffer \& Langton, 1988). Decisions about hiring, evaluation, promotion, and firing take place largely within bureaucracies, and the biggest bureaucracies had personnel departments charged with rationalizing these processes. If women systematically earn less than men and experience careers that stall out well below the top rungs of the hierarchy, organizations are the primary mechanisms that make it happen (e.g. Beckman \& Phillips, 2005). Studies documented the features of organizations associated with inequality within the firm--e.g., larger firms showed more dispersed wages, as did non-unionized firms, those with more diverse workforces, and those organized more hierarchically (Kalleberg \& Vanburen, 1994). Thus, the relevant unit of analysis for understanding differences in individual incomes is the organization. Put another way, organizations are a primary mechanism for generating inequality in society.

The literature on organizational stratification has empirical implications for society-wide inequality, but these implications have rarely been directly tested 
previously. A notable exception is a study by Sorenson \& Sorensen (2007), who examine the dispersion of wages within particular regions in Denmark. The authors suggest that changes in inequality can result from changes in corporate demography due to two types of differentiation. Vertical differentiation distinguishes organizations of the same kind (e.g., those in the same industry) on a particular dimension such as productivity or status. Increasing vertical differentiation by increasing the number of firms of the same type can increase inequality by sorting the highest quality (most productive) workers into the highest quality firms, thus increasing the dispersion of wages within that industry. On the other hand, increasing horizontal differentiation (that is, diversity in the kinds of organizations) can reduce inequality by sorting workers into firms that best match their talents. The authors find that increased numbers of organizations in the same industry operating within a region leads to increased earnings inequality, whereas wage inequality declines with greater variation in the kinds of organizations within a region.

This argument about corporate demography can be extended to explain developmental patterns in inequality at the national level. The Kuznets curve can be partly attributed to changes in the nature and size of employers due to industrialization. Economies of scale that became feasible at the turn of the 20th century encouraged the growth of very large-scale production within single organizations, often created through the consolidation of dispersed regional industries into national oligopolies (Chandler, 1977). As industries matured, they became more concentrated, bringing more of the workforce under the control of a small number of firms. The managerial innovations described by Chandler were accompanied by innovations in production methods that encouraged vertical integration on a vast scale. Ford's River Rouge plant in Dearborn, 
Michigan, for instance, employed 75,000 persons when it was completed in 1927, more than the US Department of War at that time--and it continued to grow during the Great Depression and the Second World War. Employees in vertically integrated industries were subject to more regularized bureaucratic wage policies within a firm than outside a firm, as internal labor markets replaced external ones.

Of course, what this should mean for aggregate inequality depends on the employment practices of the relevant organizations. On the one hand, corporate hierarchies are the essence of inequality, from the pyramid-shaped organization chart to the corporate jets that whisk executives to their golf outings, and earnings are more dispersed in large firms than small ones. On the other hand, the procedures for stratification--sorting and ranking--are regularized and rationalized. CEOs may be wellpaid relative to their employees, but the divergence probably does not compare with that between feudal lords and their serfs, or between hedge fund managers and temps at a call center. Moreover, organizations vary among themselves in their stratification procedures, even within the same industry (Baron \& Bielby, 1980), and increased numbers of firms within an industry are associated with greater inequality within a region (Sorensen \& Sorenson, 2007). This may imply that more concentrated employmentthat is, more workers employed by relatively fewer firms—is associated with a more equal society, while more dispersed employment is associated with greater inequality.

This tendency is amplified by the ascendance of “winner-take-all” markets, in which rewards are both highly concentrated among top performers and payoffs are determined by relative rather than absolute performance (Frank \& Cook, 1995). Due in part to the spread of information and communication technologies, and the increased 
globalization of trade, the rewards available to the world's best soprano, or golfer, or lawyer, or children's author, are now vastly greater than those available to the $4^{\text {th }}$-best soprano, golfer, lawyer, or children's author—even though the absolute differences in performance may be quite modest. Frank and Cook (1995) note several markets in which this dynamic has greatly increased incomes at the very top: book publishing, business consulting, movies and television, fashion modeling, professional sports, and executive compensation. Notably, it is only the last market—and particularly in the case of CEOs - that the market dynamics play out primarily within large organizations.

Consider a thought experiment in which a society has only one employer (say, a caricature of the USSR, or some large college towns). There would undoubtedly be a gulf in compensation between those in the Politburo and agricultural laborers--or between the football coach and an assistant professor of kinesiology. But it would not be the ocean that separates contemporary oil oligarchs and street vendors in Russia today. An illustration of this is the fact that in 2004, the 25 best-paid US hedge fund managers collectively made more than all of the CEOs of the S\&P 500 combined (Kaplan \& Rauh, 2007). Most CEOs are comfortably within the top $1 \%$ of the income scale, of course, but the truly stratospheric levels of pay occur outside corporate hierarchies. Similarly, while entry-level employees at AT\&T or GE may not have been lavishly paid, they undoubtedly beat the annual incomes of the temps that now work the landscaping crew. Inequality is closely linked to social mobility. Here too, changes in corporate organization have led to changes in patterns of mobility. Mobility refers broadly to the ability to improve one's socio-economic status. Prior research has focused largely on inter-generational mobility. That is, how much is one's class position determined by the 
class of one's parents? How likely are those born into a family in the bottom quintile of income to end up in a higher income bracket? Societies vary substantially in their levels of social mobility. Surveying the recent evidence for Europe and North America, Corak (2006) finds that half the children of poor parents in the US grow up to be poor adults, and $40 \%$ of the children of high-income parents grow up to be high-income adults, indicating relatively low levels of intergenerational mobility. In Denmark, on the other hand, children of the poor rarely grow up to be poor themselves. And as the case of Denmark illustrates, although policymakers often lament that inequality is the price one has to pay for a vibrant economy, and that efforts to reduce inequality will inevitably bring down average incomes, GDP per capita is negatively correlated with inequality cross-nationally, while the most unequal countries are also the poorest.

As with inequality, organizations are central to individual economic mobility through their hiring and promotion practices. During the post-War era in the US, the largest employers adopted systems intended to maintain and develop employees over careers that could extend up to retirement. Pensions and benefits rewarded extended commitments to the firm by premising their payouts on one's tenure with the company. Put another way, once an employee was "vested," he or she paid a price to change employers (Cobb, 2010).

Internal labor markets buffered jobs within the firm from external market forces. As Doeringer and Piore (1971) defined the term, an internal labor market was characterized by external recruiting for entry-level jobs and internal recruiting for higherlevel jobs through promotion. Jobs were typically organized into promotion ladders that provided clear paths to upward mobility. Formalized job analysis, which tied wages to 
objective characteristics of the work rather than to external market comparisons, further bureaucratized the employment relation. ILMs fit with practices of on-the-job training and worker investments in firm-specific skills (Williamson, 1975). By protecting the employment relation from the vagaries of the market, workers were guaranteed stable income and firms vouchsafed their investments in "human assets," encouraging longterm attachments between workers and firms.

In recent decades, commentators have mourned the breakdown of the system of internal labor markets and the "death of the career." Peter Cappelli (1999) describes the broad shifts in the employment relation in recent decades from a long-term commitment to a relatively short-term tryst. Paul Osterman (1996) refers to the "broken ladders" that have accompanied the breakdown of the traditional system of ILMs, making individual career paths less orderly and more likely to span multiple employers. Pfeffer and Baron (1988) were among the first to document the rise and organizational implications of temporary employment, while Barley and Kunda (2004) analyzed the longer-term prospects of the "hired gun” independent contractor. Richard Sennett (2006) describes how the new "post-corporate" employment relation discourages investment in firmspecific skills and encourages a shallow generalism rather than the kind of craft that develops with long experience. (Of course, one can have high levels of skill and pay without dedicating oneself to a particular organization—professionals such as surgeons, accountants, lawyers, and consultants fit this category.) Eileen Applebaum and her collaborators (2003) document how this new system has taken a particular toll on lowwage workers. For a generation of employees, entry-level jobs have become dead-end jobs: young men entering the labor force in the early 1990s were more than twice as 
likely to be stuck in low-wage jobs ten years later than young men entering the labor force in the early 1970s (Bernhardt, Morris, Handcock, \& Scott, 1999).

We do not want to wax nostalgic for some lost golden era of the organization man. Chinoy (1955) pointed out the stark divergence between the façade of corporate meritocracy and the experience of workers on the line, who rarely enjoyed the upward mobility promised by the American Dream. And Kafka is still the greatest chronicler of life in a bureaucracy. But with the death of the bureaucratic career has come the death of clearly-defined pathways to mobility. In a previous era--at least in theory--a kid from Brooklyn could take a job in the mailroom and work his way up to the CEO's office by understanding the game and achieving the markers of accomplishment. But the trend toward flattening hierarchies (documented by Rajan \& Wulf, 2006) limits the promotion prospects for those in management, and networks of contractors form no clear upward ladder for individual workers. Today, mobility--both upwards and downwards-resembles a game of chutes and ladders. Teenagers that create a clever social networking website might find themselves billionaires when they sell their business two years later, and homeowners that bought and sold their Las Vegas condo at the right time could retire early on their real estate winnings. On the other hand, middle managers at major corporations might find themselves unemployed when their firm is bought by a competitor; design engineers and radiologists learn that their talents are more cheaply replicated offshore; and those in the lower middle class can wind up in bankruptcy due to a sudden illness or a poorly-timed home purchase.

The implication of this discussion is that if stratification happens in organizations, then broad changes in organizational processes should lead to changes in inequality and 
mobility at the societal level. We next discuss how the corporate world in the US has organized and re-organized over the past half-century.

\section{Corporate restructuring and trends in employment concentration}

The nature of corporate employment in the US has changed substantially since Kuznets wrote in the 1950s. One master trend is the shift to post-industrialism, as the largest employers have transitioned from manufacturers such as GM to retailers like WalMart. Along the way we experienced a major merger movement in the 1960s that greatly increased employment concentration; a bust-up takeover wave in the 1980s that largely undid the mergers of the 1960s; and the rise of the "virtual” or network organization, in which networks of contractors organized by lead firms became perhaps the predominant model of industry organization in manufacturing and, to a lesser extent, services. (Following industry parlance we refer to this as the "OEM model,” for "original equipment manufacturer.”)

Post-industrialism is the dominant trend in the composition of the American labor force. In 1944, 45\% of the non-farm workforce in the US was employed in manufacturing--the high-water mark for industrial employment in the US (see Figure 2 below). ${ }^{3}$ This number quickly dropped with the end of the war and has maintained a pattern of secular decline ever since. Nonetheless, for generations the largest corporate employers were predominantly manufacturers of autos, steel, and oil. Eight of the top ten in 1950, seven of the top ten in 1960, and eight of the top ten in 1970 were manufacturers. In absolute terms, June 1979 saw the greatest number of employees in manufacturing, at $19,676,000$ (roughly $22 \%$ of the nonfarm labor force). The ten largest

\footnotetext{
${ }^{3}$ Data in this section come from the US Bureau of Labor Statistics at www.bls.gov .
} 
corporate employers in 1979 included GM, AT\&T, Ford, Sears, GE, ITT, IBM, Kmart, GTE, and Mobil. Many of these firms had topped the list since the days of the Great Depression, and their personnel policies had shaped the fates of generations of employees. Moreover, their human resource practices shaped the broader cultural context of employment, including the personnel policies of their competitors through pattern bargaining and suppliers through emulation and labor market competition (see Jacoby, 1997; Levy \& Temin, 2007, for historical accounts).

\section{Insert Figure 2 about here}

\section{Insert Table 1 about here}

Thirty years later, manufacturers employ a vanishingly small proportion of the workforce. From the turn of the 21st century to the beginning of 2010, the US lost onethird of its remaining manufacturing jobs, and at the time of this writing less than $9 \%$ of the non-farm labor force works in manufacturing. Nine of the 12 largest domestic corporate employers are in retail, with Wal-Mart at the top of the list; none were manufacturers (Davis, 2009b).

The shift from manufacturing to service has changed the characteristic nature of the employment relation among the largest employers. In manufacturing, large size tended to correspond to long employment tenure and relatively high wage and benefit packages. ILMs existed in part to vouchsafe firm-specific assets. Thus, in 2004 the median autoworker had been with his or her employer eight years; the median employee in electrical equipment and appliance manufacturing had been with their firm ten years; and those in petroleum and coal products manufacturing had 11 years' tenure (Davis, 2009a, chap. 3). Production employees in auto manufacturing in 2008 earned average 
hourly wages of over $\$ 27$. Today’s largest employers are in retail, where typical tenures are quite short: just three years on average for full-time employees. Average wages for sales employees in general merchandise stores (the most common occupation) were just over $\$ 9$ per hour in 2008. ${ }^{4}$ Correspondingly, employee turnover is often high: at WalMart, estimated turnover is $40 \%$ per year (Meyerson, 2009). The coexistence of both gargantuan size and very high turnover, as at Wal-Mart, has not been seen for generations-if ever.

At the same time, there have been several waves of corporate restructuring that changed the boundaries of firms and industries. The merger wave of the 1960s substantially increased the size of many corporations, as acquisitive conglomerates such as ITT, LTV, Litton Industries, and Gulf + Western grew dramatically through acquisition. ITT grew from 132,000 employees in 1960 to 392,000 in 1970 through several hundred acquisitions that included Hartford Insurance, Sheraton Hotels, Continental Baking (maker of Wonder Bread and Twinkies), Avis Rent-a-Car, Rayonier, Cleveland Motor, and many others. In his 1997 apologia for the conglomerate, Harold Geneen—who ran ITT through the 1960s and 1970s—explained that ITT was not just a passive holding company, buying and selling companies in its portfolio, but a relatively intrusive parent eager to impose its managerial practices on the companies it bought: "An 'operating conglomerate' is a centrally managed company that gets deep into each of its operations...Its job is to own and operate companies—ideally, through its strong, centralized management” (Geneen, 1997, pp. 21, 25). Thus did the human resource practices of one corporation spread to dozens of industries.

\footnotetext{
${ }^{4}$ Wage data come from the Bureau of Labor Statistics at www.bls.gov.
} 
The biggest firms also grew even bigger during this decade. GM added 100,000 workers during the 1960s, and AT\&T added almost 200,000 employees to its already vast labor force. (For comparison purposes, the current incarnation of AT\&T-still one of the largest US employers—-had a total of 281,000 workers as of its 2010 annual report.) By the late 1960s, through both organic growth and acquisition, employment reached a level of concentration in the US not seen before or since, providing a direct mechanism for the homogenization of human resource practices. Corporate expansion continued at a more modest pace through the 1970s, as growth by acquisition continued to be a dominant corporate strategy, taught by business schools and spread by consultants bearing growth/share matrix charts.

The relentless drive for growth that had characterized US corporations since the beginning of the $20^{\text {th }}$ century reached an abrupt halt during the 1980s. By the early part of this decade, diversified firms such as ITT faced a chronic "conglomerate discount" in which the stock market value of the whole was worth less than the parts would have been worth as free-standing companies. Moreover, the strategy of diversification had spread widely among US corporations: in 1980, the median large corporation operated in three distinct industries (Davis, Diekmann, and Tinsley, 1994). This created a great opportunity for takeover entrepreneurs that only required a few regulatory changes to unleash--in particular, a policy of reduced scrutiny of intra-industry mergers announced by the Reagan Justice Department in 1982, and a Supreme Court decision striking down state anti-takeover laws the same year. The result was a wave of so-called "bust-up" takeovers, in which undervalued conglomerates were purchased with the intention of being split back up into their component parts and either operated as free-standing 
companies or sold to buyers in related industries. During this decade, one in three Fortune 500 firms was acquired or merged, resulting in a far more industrially-focused corporate sector--and a managerial class much more attuned to share price (Davis, Diekmann, \& Tinsley, 1994).

The ambient threat of takeover prompted other firms to restructure by divesting "non-core" businesses, and through both voluntary and involuntary restructuring the largest employers substantially retrenched during the 1980s. GE's employment under CEO Jack Welch shrank from 400,000 to 300,000 between 1980 and 1985, and other firms followed GE’s example. Meanwhile, AT\&T was forced to break up into a longdistance company and seven regional "Baby Bells" in 1984, and Lucent was subsequently separated from AT\&T in 1996. By the early 1990s, large-scale layoffs had become a common (if not fully legitimate) element in the CEO’s toolkit (Budros, 1997), and even prototypical career employers such as IBM and AT\&T joined the movement to "streamline" their employment. Those who had joined such firms out of college in the expectation of a comfortable career protected by an internal labor market found a new deal at work (Cappelli, 1999). Even the notion of what is "core" became more flexible. In the American auto industry, which had been among the most vertically integrated in the world, the two largest players spun off major parts suppliers into (more or less) freestanding companies. GM spun off Delphi in 1999 (immediately creating a new Fortune 100 company), while Ford spun off Visteon the following year.

After the bust-ups of the 1980s and the advent of activist shareholders, corporate elites became far more attuned to the consequences of their strategies for "shareholder value," not least because of the widespread adoption of option-based compensation 
practices that tied their personal wealth to the company's market value. The quest to create shareholder value took on almost religious aspect among corporate elites. Corporate mission statements of the late 1990s routinely announced that the corporation existed to “create shareholder value,” with the company's actual business (sodas, sneakers, pharmaceuticals, online pornography) serving as means to that end (Davis, 2009a, chap. 3). Announcements of acquisitions, spinoffs, or restructurings in the 1990s were inevitably accompanied by a nod to Wall Street, which made clear its preference for “intellectual property" over tangible assets. This in turn led to the widespread adoption of an OEM or network model of organization and the disaggregation of employment across firms.

The prototype of the contemporary OEM corporation is Nike. Nike designs and markets sneakers and athletic gear sold around the world, and its familiar "swoosh" logo represents one of the most recognized brands ever created. Yet in spite of its global dominance in athletic apparel, Nike employees a mere 34,300 persons. Quoting the company’s 2009 10K, "Virtually all of our footwear is produced outside of the United States. In fiscal 2009, contract suppliers in China, Vietnam, Indonesia and Thailand manufactured 36\%, 36\%, 22\% and 6\% of total NIKE brand footwear, respectively... Our largest single footwear factory accounted for approximately 5\% of total fiscal 2009 footwear production.” The firm itself is the central node in a network of supply chains stretching around the world, from production to distribution, but its own employees engage primarily in the high-end tasks R\&D and marketing.

The Nike model has been widely emulated across a variety of industries, to the evident delight of Wall Street analysts. In explaining his own firm's move to “de- 
verticalize” by selling off its factories to contractors in 1997, Sara Lee CEO John Bryan stated, "Wall Street can wipe you out. They are the rule-setters. They do have their fads, but to a large extent there is an evolution in how they judge companies, and they have decided to give premiums to companies that harbor the most profits for the least assets." Corporations increasingly look like the nexus-of-contracts described by financial economists, with intellectual property (patents, trademarks, brands, product designs, marketing savvy) residing at the center.

It is not just the manufacturing sector that has embraced outsourcing. Thanks to the pervasive spread of high-speed Internet connections, services are also increasingly susceptible to offshoring. Blinder (2006) estimated that perhaps 40 million service jobs in the US faced competition from overseas, from tutoring schoolkids via Skype to processing mortgage applications to decoding the human genome. Offshoring allows firms to grow to great scale with relatively few direct employees. Indeed, Californiabased Vizio — the largest brand of LCD televisions in the US, with a 22\% market sharehad only 160 employees as of 2009, as assembly and supply chain management are done by contractors in Taiwan (http://www.vizio.com/about/).

One result is that it is increasingly difficult to determine who actually produced the goods and services we consume. Designer clothing has long been created by contractors, of course. Consumer electronics are overwhelmingly produced by unknown "board stuffers” such as Solectron, Ingram Micro, Jabil Circuit, and others--not Apple, Hewlett-Packard, Sony, Dell, or other firms that furnished the brand. Dozens of competing pet food brands are manufactured by the same vendor in Ontario--a fact that was revealed when it turned out the chow had been tainted with melamine further up the 
supply chain. Baxter Health's blood thinner Heparin was recalled when it killed dozens of patients and injured hundreds more due to toxins in the raw materials procured by its Chinese manufacturer. And even prisoner interrogations and CIA assassinations have been handed off to contractors (see Davis, 2009a for elaboration). Thus, due to broad corporate restructuring toward an “OEM economy," prospects for career advancement within a particular firm are dim, as the more typical form of organization is the network of contractors.

Corporate restructuring is one mechanism standing between the rise of finance and increased inequality. Scholars have noted another: the meteoric rise of compensation levels on Wall Street, which is disproportionately responsible for the rise in overall inequality in the US (Kaplan \& Rauh, 2007). Goldman Sachs employees earned an average of more than $\$ 700,000$ apiece in 2009 , and their colleagues in hedge funds routinely earned large multiples of this amount. As faculty in business schools can attest, the most remunerative jobs by far are in finance, and particularly in the smaller freestanding entities such as hedge funds.

Summarizing, the American economy has shifted in ways that are potentially consequential for economic inequality, particularly if we view organizations as critical mechanisms for stratification. Employment became far more concentrated during the 1960s due both to organic growth among the largest firms and through acquisition-driven growth among the new conglomerates. During the 1980s, many of the largest firms were acquired and broken back up, while others voluntarily restructured or downsized, thus lowering overall employment concentration. This trend accelerated during the 1990s, through layoffs and divestitures, and the 2000s, with the spread of the OEM model. 


\section{Data}

We now move to an exploration of newly-available data on the connection between employment concentration and inequality both within the US and around the world. Our expectation going in was that increased concentration would be modestly associated with lower levels of income inequality. The findings show that this relationship is surprisingly strong. We first describe the sources of the data and define our measures. We then present time-series data for the United States from 1950 to 2006, and cross-national comparisons for 53 countries in 2006.

\section{Measuring social inequality: the Gini coefficient}

The Gini coefficient measures the extent to which the distribution of income or consumption among individuals or households deviates from a perfectly equal distribution. The Lorenz curve (Lorenz, 1905) is a graphical representation of cumulative income share on the vertical axis and the distribution of the population on the horizontal axis. Specifically, each point on the Lorenz curve represents the share of income held by X-percent of the population (see Figure 3 below). The Gini coefficient (Gini, 1913), the most commonly used measure of inequality, measures the percentage of area that lies between the Lorenz curve and a line of perfectly equality. The coefficient varies between 0 , which represents complete equality and 1 , which indicates complete inequality (i.e. one person controls all income). Typically, the Gini coefficient is represented in percentage terms. Because the Gini coefficient is scale independent it allows for comparisons across countries or regions. The primary advantage of using the Gini coefficient to measure inequality is that, unlike GDP statistics, it represents a distribution across the entire population within a country. Absolute levels of average poverty or wealth are compatible with either high or low inequality. In 2006, the Gini coefficient and GDP per capita were 
correlated at the -0.43 level among 73 countries in the World Development Indicators database. As Figure 4 shows, low levels of GDP per capita are consistent with a wide range of levels of inequality, whereas high levels of GDP per capita are consistent with both low and moderate levels of inequality.

\section{Insert Figure 3 about here \\ Insert Figure 4 about here}

\section{US data}

Historical Gini coefficient data for the United States came from the World Income Inequality Database (2008). This database compiles longitudinal inequality data from a variety of sources for 166 countries. It is common that there are multiple entries for a country in a given year - typically based on calculations with different units of analysis (e.g individual or household) and different definitions of income (e.g. net, gross, disposable). Because slightly different measures of inequality are obtained based upon the unit of analysis and income source it is important to use consistent measures over time. There were two sources in the World Income Inequality Database that used the same unit of analysis and definition of income in calculating the Gini coefficient for the years 1950 to 2006. The Gini data for years 1950 to 1967 came from Brandolini (1998),

and the US Census Bureau provided data from 1968 to 2006. Household, gross monetary income was used in all calculations and both sources relied on data taken from the Current Population Survey.

Our primary independent variable is employment concentration, defined as the ratio of the number of workers employed by the 10 (or 25, or 50, or 100) largest domestic corporations and the size of the overall workforce. To the best of our knowledge, this 
chapter is the first use of this measure in the literature. Of course, industrial organization economists and antitrust authorities have long used the four-firm (or eight-firm) concentration ratios based on sales to analyze the level of competition within an industry. These statistics calculate the proportion of an industry's total revenues accounted for by the four largest participants; high concentration ratios were taken as evidence of oligopoly. Our measure is analogous but differs in that (1) we are indifferent as to industry, and (2) our denominator is the entire workforce of a nation.

Corporate employment data came from Compustat and company 10Ks. Firms typically report the size of their overall workforce, both domestic and foreign, and this is the number provided in Compustat. Some (but not all) also report separate figures for domestic and foreign employment, but this is only available by manually reading annual 10K statements. We did this for all large US firms beginning in 1994 (the year the SEC opened the possibility of on-line financial disclosures). Unfortunately, it was not feasible to track archives of all annual 10K statements back until 1950. We opted instead to use the Compustat figures for employment for consistency over time. During the years of our study when both figures were available, the correlation between annual employment by the top 10 employers using the Compustat figures for overall employment and the figures for domestic-only employment from 10Ks was .95. This suggests that aggregate domestic and global employment were roughly proportional, and that our measure of concentration is a reasonable proxy. Figure 5 compares data from Compustat and our hand-compiled data from corporate 10K statements for all available years.

\section{Insert Figure 5 about here}


Labor force data came from the United States Bureau of Labor Statistics (www.bls.gov). The size of the labor force is defined as the sum of all employed and unemployed persons. We also used a measure of labor force excluding farm workers and one excluding non-government workers, and the results were similar.

We compiled employment concentration using the largest 10, 25, and 50 corporate employers, and found that these numbers were correlated at over .87 over time. Because it was often difficult to consistently locate firms beyond the ten largest outside the US, we use the 10-firm employment concentration ratio in our analyses. Based on 57 years of data from the US case, we argue that the size of the ten largest employers is roughly proportional to the sizes of the next tiers of large employers. In other words, employment concentration among the biggest firms is an indicator of a broader underlying tendency toward large (or small) organizations relative to the size of the economy.

\section{Global data}

For our cross-national comparison we report data for the year 2006, the most recent year for which we have inequality data available. Gini and labor force size data are available from the World Bank’s World Development Indicators (2008).

Data on the largest firms came from two sources, the WorldScope Global (2006) database supplemented by data from the Orbis online database (2009). We downloaded all companies available from WorldScope for the year 2006 and identified the 10 largest companies per country. There were 37 countries for which there were enough companies to create a reliable employment concentration figure. In an effort to include the maximum number of countries as possible, we then used Orbis to construct measures for 
countries not covered by WorldScope. One issue with the Orbis is that the employment data for many companies is not available. Therefore, we examined the largest non-public firms based on total revenue, keeping countries for which there was employment data for 7 of the largest 10 and 10 of the largest 15 firms in terms of revenue. This provided 18 additional countries to our sample, giving us 53 total countries. ${ }^{5}$

\section{Findings}

\section{The United States, 1950-2006}

Figure 6 shows the 3-year moving average of employment concentration and the 3-year moving average of the Gini coefficient for the United States between 1950 and 2006. The wave of industrial consolidation throughout of the 1960s and early 1970s had considerable impact on employment growth among America’s largest firms. Between 1968 and 1973, the United States had its six highest years of employment concentration. The lowest level of inequality came in 1968, when the Gini was 38.7. Of the ten years of lowest inequality, six are among the ten years of highest employment concentration. The cumulative effect of hostile takeovers, spin-offs and bust-ups in the 1980s had an equally profound effect on employment among America’s largest companies. Employment concentration began to decline from the early 1980s through the early 1990s where concentration levels have remained low. The years 2003 and 2004 shared the highest levels of inequality, where the Gini coefficient reached 46.4. Of the ten years of highest inequality, five are among the ten years of lowest employment concentration.

\section{Insert Figure 6 about here}

\footnotetext{
${ }^{5}$ Though used by other researchers in creating country-level measures of business concentration (e.g. La Porta et al. 2007), one limitation of the WorldScope data is that it does not include privately-held companies. This may understate the level of employment concentration in some countries.
} 
Not surprisingly, the correlation between employment concentration and inequality in the United States annually is very high, at -0.80 . The data presented here suggests that inequality and concentrated employment in the United States are highly and negatively related over time. We would argue that these results are causal: employment concentration, through the organizational mechanisms we have described above, lowers overall income inequality across the economy.

Figure 7 provides an alternative way to visualize the historical trajectory of employment concentration and inequality over time. Each point represents the values of these two dimensions for a given year, and lines connect one year to the next, from the beginning to the end of our sample period. A downward slope indicates changes over time consistent with the narrative we have described. As is clear from the Figure, there were three eras of significant shifts in the profile of concentration and inequality: the 1960s, when concentration increased and inequality declined; the 1980s, when concentration decreased and inequality rose; and the 1990s, when concenctration further decrased and inequality leapt. Interestingly, as Figure 7 shows, this trend reversed during the 2000s, as employment concentration increased again, while inequality correspondingly declined.

\section{Insert Figure 7 about here}

Alternative interpretations normally take two broad forms: the implied causal relationship is actually reversed (in this case, inequality causes lower employment concentration, rather than the other way around), or a third factor creates a spurious relation. The first is difficult to rule out on statistical grounds: regressing inequality on concentration yields much the same results as regressing concentration in inequality, with 
various forms of lag and assorted control variables (size of the labor force, unemployment, the proportion of the workforce in manufacturing —all of which have a significant negative effect on inequality). But the best model fit by far (see Table 2 below), is one in which inequality in the current year is a function of employment concentration in the current year, unemployment in the current year, and the proportion of the workforce employed in manufacturing (which, as we have discussed, is monotonically decreasing throughout the sample period—see Figure 2). Moreover, it is difficult to conceive of a process in which inequality has a short-term effect on corporate concentration in quite the same way that concentration has an almost mechanical effect in reducing inequality. It is possible to theorize longer-term processes in which, say, inequality reduces ambient trust in society, which in turn reduces the feasible size of the largest organizations (cf. LaPorta, Lopez-deSilanes, Shleifer, \& Vishny, 1997), but such

processes are unlikely to take place over the short periods in which we observe reversals in trends in both concentration and inequality. We return to this interpretation when we describe the cross-national findings below.

\section{Insert Table 2 about here}

Another alternative explanation for these findings is that increasing inequality is due to declining rates of unionization. If true, this could create a potentially spurious relation between employment concentration and inequality via rates of unionization. Organized labor is often credited for the role it played in the dramatic growth of the middle class in the U.S. during the 1950s and 60s (see Dubofsky, 1994; Levy \& Temin, 2007). After the Second World War, a system of corporate-sponsored health care, pensions, and wage security was enshrined in the so-called "Treaty of Detroit" (Bell, 
1950), a grand labor agreement negotiated in 1950 between General Motors and the United Auto Workers. The two cornerstones of this contract were that it linked wage increases to productivity improvements and secure, long-term employment was guaranteed for worker loyalty (Osterman, Kochan, Locke, \& Piore, 2001, chap. 1). The major features of the Treaty of Detroit eventually spread throughout many industries and influenced human resource practices in most of the largest firms. The end result of this process was sustained and dramatic improvement in wages and benefits for many working-class citizens, and a corresponding decrease in inequality (Levy \& Temin, 2007)—at least over part of the period we examine.

To illustrate, in 1922 the average machine operator in the auto industry earned 66 cents per hour. By 1940 (after the advent of the United Auto Workers) average earnings were 96 cents per hour, and by 1957 they grew to $\$ 2.29$ per hour (Macdonald, 1963, p. 138). Additionally, in 1947 General Motors paid an average of 18 cents per hour in fringe benefits to employees; by 1960 that had increased to 72 cents per hour (Macdonald, 1963, p. 40). That same machine operator in the early 1970s earned more in real terms than a manager had earned in 1950 (Levy \& Temin, 2007). There is little debate that these wage and benefit increases were influenced by organized labor. Thus, it is likely that declines in unionization help explain rising inequality; in fact, the correlation between union density rates and the Gini coefficient is -0.59 . However, as Figure 4 indicates, rates of unionizaton have experienced an almost continuous secular decline since the late 1950s, while inequality—like employment concentration—has exhibited a more varied pattern. Indeed, the sharp decline in inequality from 1962 to 1972 coincides with significant decreases in unionization. Though we cannot rule out the 
possibility that unionization density rates do not adequately reflect the influence of organized labor on wage patterns, declines in unionization do not appear to be a sufficient explanation to explain the changes in inequality in America over time. ${ }^{6}$

\section{Insert Figure 8 about here}

Of course, our examination of the post-War era in the US is essentially a case study. Other explanations are more readily considered in the context of cross-national comparisons, which we turn to next.

\section{Cross-national comparisons, 2006}

Figure 9 shows the link between employment concentration and inequality at the country level. The correlation between income inequality and employment concentration among our cross-section of countries is -0.47 , providing additional evidence for a relationship between inequality and the prevalence of large corporate employers within a country. One of the most striking features of Figure 9 is the extent to which “neighborhoods” in the diagram correspond to geographic regions which, in turn, correspond to different models of national economic organization or "varieties of capitalism” (cf. Hall \& Soskice, 2001). Amable (2003) distinguishes five broad configurations of capitalism at the national level: a social democratic or Nordic model; a Meditarranean/Southern European model; a Continental European model, corresponding primarily to Western Europe; an Asian model that encompasses Japan and Korea; and a neoliberal (primarily Anglophone) model. Each has distinct clusters of features when it comes to labor market institutions, social welfare provision, systems of financial intermediation, and product market dynamics.

\footnotetext{
${ }^{6}$ For example, it is possible that during this 10-year period non-union firms, in the attempt to stave off organized labor, continued to increase wages thereby understating the influence of union strength during this period
} 


\section{Insert Figure 9 about here}

We find similar clustering in Figure 9 documenting the link between employment concentration and inequality. The Nordic countries are spread over the bottom of the lower right quadrant, with low inequality and relatively concentrated employment. Continental European countries have higher inequality but generally lower levels of employment concentration—although here we find, as did Amable (2003), that Switzerland and the Netherlands are outliers, with high levels of employment concentration relative to other non-Nordic European countries. Meditarranean countries form a cluster with similar levels of inequality but less concentrated employment. Intriguingly, Japan and Korea are clustered on the off-diagonal with most former state socialist countries, Austria, and Germany, where both inequality and concentration are relatively low. Other Asian countries (including China, Malaysia, the Philippines, Thailand, and India) exhibit substantially higher levels of inequality and relatively lower levels of concentration, undermining the notion of a single “Asian model." Finally, we find that the Anglophone countries defy a clear clustering and exhibit rather varied patterns of inequality and concentration, with the US being particularly distinguished by its high level of inequality.

We also find two other clusters that do not correspond to any identifiable "variety of capitalism.” At the very highest levels of inequality and the lowest levels of concentration are the Latin American countries. In Colombia, the most unequal country in our sample, no single firm employs as many as 10,000 people-in spite of the fact that the nation contains a population of 45 million people. (Denmark, by contrast, contains just 5.5 million people but houses two firms employing over 200,000 persons each.) 
Below the "Latin quarter" is a cluster of African and Asian countries, with moderate levels of inequality but relatively low levels of concentration.

The United States is effectively in the middle, with moderate levels of concentration and moderate-to-high inequality. It is comparatively close to countries such Sri Lanka, Tunisia, Ghana, Senegal and the Russian Federation in terms of inequality, while its neighbor to the north, Canada, much more closely resembles a European country. In a sense, the US fits no cluster.

Broadly speaking, the cross-national results corroborate the pattern within the US showing a link between the nature of corporate organization and society-wide levels of inequality. But such a link is not a simple one-to-one matching. Rather, the observed pattern of relations indicates that there is a "wedge": low employment concentration is compatible with both great inequality (the Latin American economies) and relative equality (the former state socialist countries), but high concentration seems to drive out inequality. We explore this idea in the next section.

\section{Discussion}

Both over time within the US and cross-nationally, income inequality covaries strongly with the extent to which a substantial part of the labor force is employed by a relatively small number of firms. The degree of employment concentration is a concept new to the organizational literature, yet as our findings here document, there is good reason to believe that it has a strong causal connection with economic inequalityspecifically, that increasing concentration reduces overall inequality.

Based on the American case, the link between concentration and inequality may be straightforward. As more employees are brought within the control of a single 
employer, their compensation becomes subject to bureaucratic rationalization. Salaries vary by hierarchical level, of course, but the extent of disjunture from one level to the next is limited, with the possible exception of the very apex. Extremes at the top and bottom of the economy's income distribution are more likely to occur outside the corporate ambit. At the very top are winner-take-all markets for individual talents, or boutique firms such as investment partnerships in which stratospheric salaries might be shared by a small number of partners. The very bottom is characterized by intermittent employment with relatively tentative attachments. Corporate employers occupy the middle; to the extent that employment is concentrated within them, overall inequality is reduced.

This account suggests that the logically prior question is, What accounts for organizational size? Why is it that at some times and in some places "small is beautiful," while at other points bigger is better? Here, the cross-national evidence is rich with implications. We find that low employment concentration is compatible with a wide range of inequality, from relatively equal former socialist countries such as Hungary and the Czech Republic to the wild extremes of inequality in Brazil and Colombia. But as employment becomes more concentrated, the top levels of inequality are attenuated. As with all cross-sectional comparisons (and particularly cross-national ones), a range of alternative interpretations is possible. Perhaps a basic level of horizontal trust within a society is necessary to build relatively large-scale organizations (cf. LaPorta et al., 1997), and inequality corrodes trust. Put another way, relative equality engenders trust, which enables large-scale organizing. This might help explain the paucity of large organizations in countries with troubled histories such as Colombia, Chile, and 
Argentina, and the relative gigantism of several companies in Scandinavia, where ambient interpersonal trust is high. It also implies that, other things equal, former socialist countries would have an easier path to growing large domestic businesses than Latin countries. On the other hand, the case of Russia sits uneasily with this account, as it is home to some of the largest firms in the world (such as Gazprom, Rosneft and Lukoial - each among the 100 largest firms in the world), yet ambient trust is relatively low, and inequality is moderate to high (at about the same level as the US).

Our findings suggest that variation in organizational size is likely to depend on several factors, including interactions among technology, national culture, and managerial ideologies. To date, this topic has received almost no attention. But it suggests another avenue by which conceptions of the corporation, its purpose, and its place in society influence broader social outcomes.

\section{Conclusions}

In this chapter we have introduced the concept of employment concentration and linked it to inequality at the societal level. Focusing primarily on the case of the United States, we have argued that employment concentration- the extent to which a large proportion of the labor force is employed by the largest firms, rather than dispersed among smaller firms_-reduces the overall level of income inequality in an economy, as more of the workforce is brought under the wage and employment practices of a smaller set of firms. We call this the paradox of hierarchy: corporations are generally hierarchical, with those at the top earning incomes many times larger than those at the bottom, and larger firms are more hierarchical than smaller firms. Yet societies in which more of the workforce is employed in the largest firms are more equal overall than those 
where employment is spread more widely. Our data and narrative track this regularity over the post-War American economy, documenting a clear co-movement between employment concentration and inequality.

We attribute the most recent explosion of inequality in the US in part to financedriven corporate restructuring that has favored the dispersal of employment among OEM networks. This organizational explanation contrasts with the standard economic account, which attributes inequality to technologically-driven changes in the skill mixes required by high-paying jobs. If the standard account were true, we might expect to see radical increases in inequality among countries in the technological vanguard. But cross-national comparisons belie this account, as many of the most technologically advanced economies are also among the least unequal. Japan and the Nordic countries are among the most economically equal societies in the world, and Germany and Korea experience far less inequality than the US. We argue that organizational employment practices are the proximal cause of more or less social inequality. As Pfeffer (2010) has recently argued, environmental sustainability has become central on the agenda of corporate managers even as "human sustainability” has fallen off. We hope that this paper provides one avenue into addressing this concern.

Organizational practices are not the only factor influencing inequality, of course. But the data we present suggest an intriguing theoretical role for organization theory in linking economic change and societal outcomes, such as inequality. Our findings open up a potentially fruitful new area of research. Availability of better data going forward will allow a more fine-grained understanding of the processes generating societal mobility and inequality. In future work, we anticipate analyzing cross-national data 
similar to the American case we have analyzed here. If the US is not unique, then we may be able to provide a robust explanation of social inequality rooted in organization theory. 


\section{References}

Acemoglu, D. (2002). Technical change, inequality, and the labor market. Journal of Economic Literature, 40(1), 7-72.

Alesina, A., \& Rodrik, D. (1994). Distributive Politics and Economic Growth. Quarterly Journal of Economics, 109(2), 465-490.

Amable, B. (2003). The diversity of modern capitalism. Oxford, UK: Oxford University Press.

Applebaum, E., Bernhardt, A. D., \& Murnane, R. (2003). Low-wage America: how employers are reshaping economic opportunity in the workplace. New York: Russell Sage.

Baron, J. N., \& Bielby, W. T. (1980). Bringing the Firms Back in - Stratification, Segmentation, and the Organization of Work. American Sociological Review, 45(5), 737-765.

Beckman, C. M., \& Phillips, D. J. (2005). Interorganizational determinants of promotion: Client leadership and the attainment of women attorneys. American Sociological Review, 70(4), 678-701.

Bell, D. (1950, July). The Treaty of Detroit. Fortune, 53.

Bernhardt, A., Morris, M., Handcock, M. S., \& Scott, M. A. (1999). Trends in job instability and wages for young adult men. Journal of Labor Economics, 17(4), S65-S90.

Blau, P., \& Duncan, O. D. (1967). The American Occupational Structure. New York: John Wiley.

Blinder, A. S. (2006). Offshoring: The next industrial revolution? Foreign Affairs, 85(2), 113-128.

Brandolini, A. (1998). A Bird's-Eye View of Long-Run Changes in Income Inequality: Banca d'Italia.

Budros, A. (1997). The new capitalism and organizational rationality: The adoption of downsizing programs, 1979-1994. Social Forces, 76(1), 229-249.

Cappelli, P. (1999). The new deal at work: Managing the market-driven workforce. Boston, MA: Harvard University Press.

Chandler, A. D. (1977). The Visible Hand: The Managerial Revolution in American Business. New York: Belknap Press.

Chinoy, E. (1955). Automobile workers and the American dream. Garden City, NY: Doubleday.

Cobb, J. A. (2010). The Employment Contract Broken? The Deinstitutionalization of Defined Benefit Retirement Plans. Paper presented at the Annual Meeting of the Academy of Management.

Corak, M. (2006). Do Poor Children Become Poor Adults? Lessons from a CrossCountry Comparison of Generational Earnings Mobility. Research on Economic Inequality, 13, 143-188.

Davis, G. F. (2009a). Managed by markets: how finance reshaped America. New York: Oxford University Press USA.

Davis, G. F. (2009b). The rise and fall of finance and the end of the society of organizations. Academy of Management Perspectives 23(3), 27-44. 
Davis, G. F., Diekmann, K., \& Tinsley, C. (1994). The Decline and Fall of the Conglomerate Firm in the 1980s: The Deinstitutionalization of an Organizational Form. American Sociological Review, 59(4), 547-570.

DiMaggio, P. J., \& Powell, W. W. (1983). The Iron Cage Revisited - Institutional Isomorphism and Collective Rationality in Organizational Fields. American Sociological Review, 48(2), 147-160.

Doeringer, P., \& Piore, M. J. (1971). Internal Labor Markets and Manpower Analysis. Lexington, MA: D.C. Heath and Company.

Dubofsky, M. (1994). The state and labor in modern America. Chapel Hill, NC and London, England: The University of North Carolina Press.

Firebaugh, G. (1999). Empirics of world income inequality. American Journal of Sociology, 104(6), 1597-1630.

Frank, R. H., \& Cook, P. J. (1995). The Winner-Take-All Society. New York: Free Press.

Geneen, H. (1997). The Synergy Myth. New York: St. Martin's.

Gini, C. (1913). Variabilita e Mutabilita. Journal of the Royal Statistical Society, 76(3), 326-327.

Hall, P. A., \& Soskice, D. (2001). Varieties of capitalism: the institutional foundations of comparative advantage. New York: Oxford University Press Inc.

Jacoby, S. M. (1997). Modern manors: Welfare capitalism since the New Deal. Princeton, NJ: Princeton University Press.

Kalleberg, A. L., \& Vanburen, M. E. (1994). The Structure of Organizational Earnings Inequality. American Behavioral Scientist, 37(7), 930-947.

Kaplan, S. N., \& Rauh, J. (2007). Wall Street and Main Street: What Contributes to the Rise in the Highest Incomes? National Bureau of Economic Research, Inc.

Kuznets, S. (1955). Economic Growth and Income Inequality. American Economic Review, 45(1), 1-28.

LaPorta, R., Lopez-deSilanes, F., Shleifer, A., \& Vishny, R. W. (1997). Trust in large organizations. American Economic Review, 87(2), 333-338.

Levy, F., \& Temin, P. (2007). Inequality and Institutions in 20th Century America. Massachusetts Institute of Technology Department of Economics.

Lorenz, M. O. (1905). Methods of measuring the concentration of wealth. Publications of the American Statistical Association, 9, 209-219.

Macdonald, R. M. (1963). Collective Bargaining in the Automobile Industry: A Study of Wage Structure and Competitive Relations. New Haven, CT: Yale University Press.

March, J. G., \& Simon, H. A. (1958). Organizations. New York: Wiley.

Mellor, J. M., \& Milyo, J. (2001). Reexamining the evidence of an ecological association between income inequality and health. Journal of Health Politics Policy and Law, 26(3), 487-522.

Meyerson, H. (2009). In Wal-Mart's Image [Electronic Version]. American Prospect.

Retrieved March 30, 2010 from

http://www.prospect.org/cs/articles?article=in_walmarts_image.

Orbis (Retrieved September, 2009), Bureau van Djik.

Osterman, P. S. (1996). Broken ladders: managerial careers in the new economy. New York: Oxford University Press. 
Osterman, P. S., Kochan, T. A., Locke, R. M., \& Piore, M. J. (2001). Working in America: a blueprint for the new labor market. Cambridge, MA: MIT Press.

Partners, W. D. (2006). WorldScope global 2006: Bridgeport, CT.

Perotti, R. (1993). Political Equilibrium, Income-Distribution, and Growth. Review of Economic Studies, 60(4), 755-776.

Pfeffer, J., \& Langton, N. (1988). Wage Inequality and the Organization of Work - the Case of Academic Departments. Administrative Science Quarterly, 33(4), 588606.

Piketty, T., \& Saez, E. (2003). Income inequality in the United States, 1913-1998. Quarterly Journal of Economics, 118(1), 1-39.

Rajan, R. G., \& Wulf, J. (2006). The, flattening firm: Evidence from panel data on the changing nature of corporate hierarchies. Review of Economics and Statistics, 88(4), 759-773.

Robinson, W. S. (1950). Ecological correlateions and the behavior of individuals. American Sociological Review, 15, 351-357.

Sennett, R. (2006). The culture of the new capitalism. New Haven, CT: Yale University Press.

Sorensen, J. B., \& Sorenson, O. (2007). Corporate demography and income inequality. American Sociological Review, 72(5), 766-783.

Wilkinson, R., \& Pickett, K. (2009). The spirit level: why more equal societies almost always do better. London: Penguin Publishing.

Williamson, O. E. (1975). Markets and Hierarchies: Analysis and Antitrust Implications. New York: Free Press.

World Development Indicators (2008) ( Retrieved September, 2009), World Bank Group

World Income Inequality Database (2008) (Retrieved November 13, 2009), United Nations University - World Institute for Development Economics Research: http://www.wider.unu.edu/research/Database/en_GB/database/ 
Table 1. Largest 10 Employers in the U.S., 1950-2009

\begin{tabular}{|l|l|l|l|}
\hline \multicolumn{1}{|c|}{1950} & \multicolumn{1}{c|}{1960} & \multicolumn{1}{c|}{1970} & \multicolumn{1}{c|}{1980} \\
\hline AT\&T Corp & General Motors Corp & AT\&T Corp & GT\& Corp \\
\hline General Motors Corp & AT\&T Corp & General Motors Corp & Ford Motor Co \\
\hline United States Steel Corp & Ford Motor Co & Ford Motor Co & General Electric Co \\
\hline General Electric Co & General Electric Co & General Electric Co & Sears Roebuck \& Co \\
\hline Sears Roebuck \& Co & United States Steel Corp & ITT Industries Inc & IBM Corp \\
\hline Bethlehem Steel Corp & Sears Roebuck \& Co & Sears Roebuck \& Co & ITT Industries Inc \\
\hline & $\begin{array}{l}\text { Great Atlantic \& Pacific Tea } \\
\text { Ford Motor Co }\end{array}$ & IBM Corp & Kmart Corp \\
\hline Chrysler Corp & Exxon Corp & Western Electric Co Inc & Mobil Corp \\
\hline Exxon Corp & Bethlehem Steel Corp & United States Steel Corp & GTE Corp \\
\hline Westinghouse Electric Corp & ITT Industries Inc & & \\
\hline
\end{tabular}

\begin{tabular}{|l|l|l|}
\hline \multicolumn{1}{|c|}{$\mathbf{1 9 9 0}$} & \multicolumn{1}{c|}{$\mathbf{2 0 0 0}$} & \multicolumn{1}{c|}{$\mathbf{2 0 0 8}$} \\
\hline General Motors Corp & Wal-Mart Stores & Wal-Mart Stores \\
\hline Sears Roebuck \& Co & General Motors Corp & United Parcel Service Inc \\
\hline IBM Corp & McDonald's Corp & McDonald's Corp \\
\hline Kmart Corp & Unted Parcel Service Inc & IBM Corp \\
\hline Ford Motor Co & Ford Motor Co & Target Corp \\
\hline Wal-Mart Stores & Sears Roebuck \& Co & Yum Brands Inc \\
\hline Pepsico Inc & IBM Corp & Citigroup Inc \\
\hline General Electric Co & General Electric Co & Kroger Co \\
\hline AT\&T Corp & Kroger Co & Sears Holding Corp \\
\hline Olsten Corp & J C Penney Co & General Electric Co \\
\hline
\end{tabular}


Table 2. Time-series regression estimates of Income Inequality in the U.S., 1950-2006

\begin{tabular}{|c|c|c|}
\hline \multirow[t]{2}{*}{ Variables } & \multicolumn{2}{|c|}{ Model 1} \\
\hline & Coefficient & Standard Error \\
\hline Unemployment (\%) & $-.551^{* * *}$ & .106 \\
\hline Union Density (\%) & -.024 & .032 \\
\hline Employment Concentration (\%) & $-2.947^{* * *}$ & .387 \\
\hline Constant & $56.795^{* * *}$ & 1.216 \\
\hline Observations & & 57 \\
\hline $\mathrm{R}^{2}$ & & .7571 \\
\hline $\begin{array}{l}{ }^{*} \mathrm{p}<.05 ;{ }^{* *} \mathrm{p}<.01 ;{ }^{* * *} \mathrm{p}<.001 \\
\text { Tests are two-tailed }\end{array}$ & & \\
\hline
\end{tabular}


Figure 1. Income Inequality in the U.S., 1950 - 2006

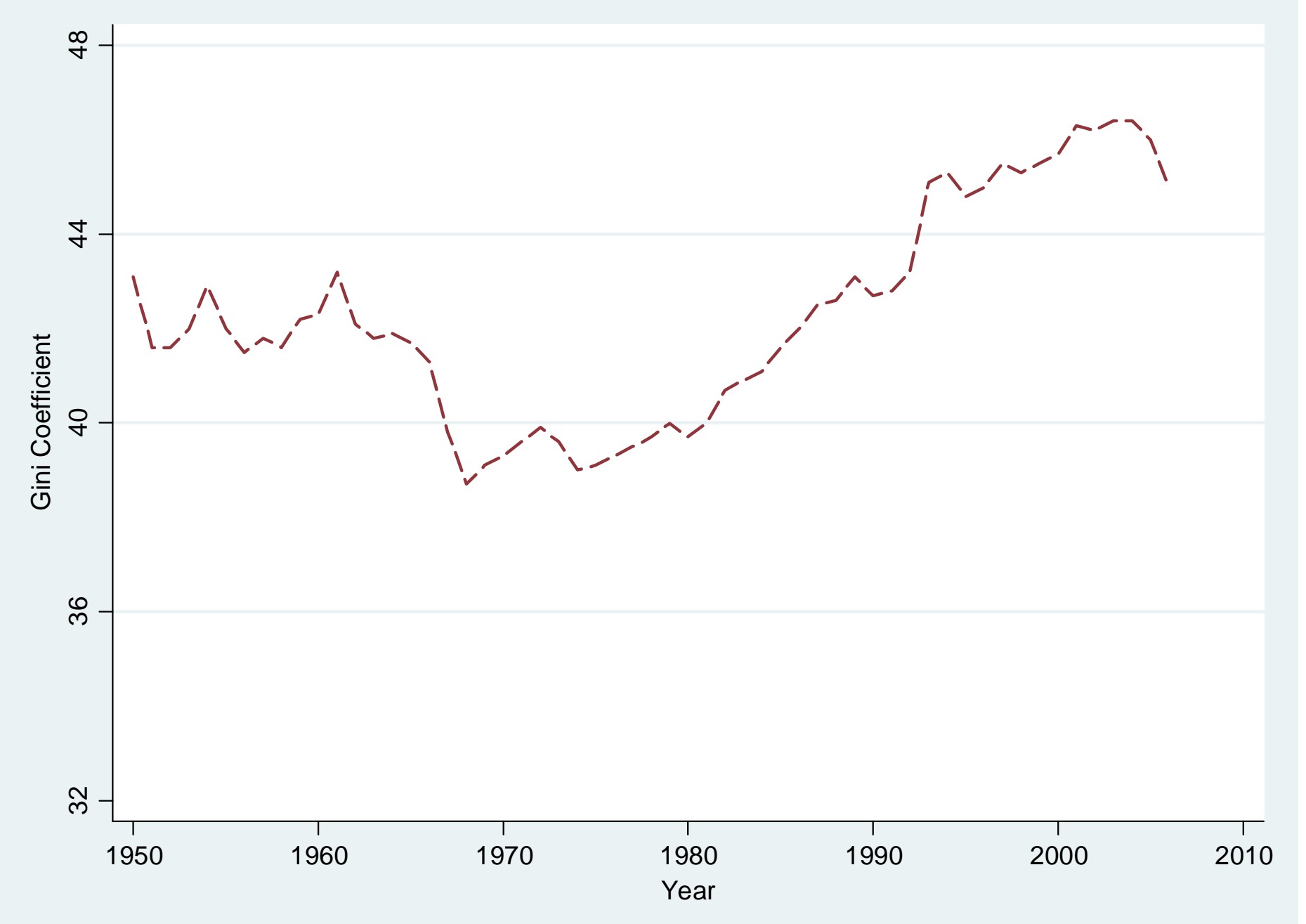


Figure 2: Percentage of U.S. Labor Force Employed in Manufacturing and Services, 1938-2008

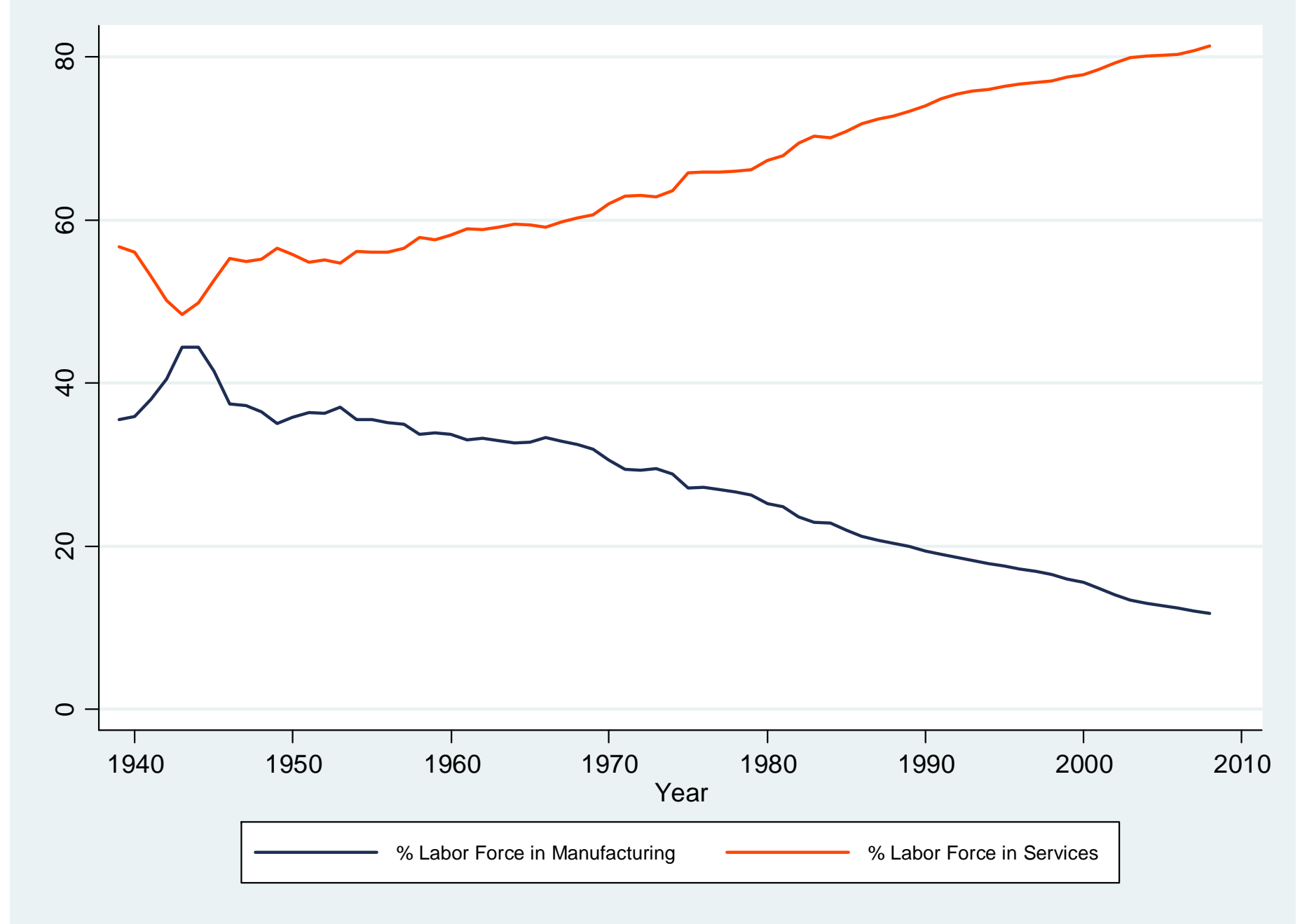


Figure 3. Lorenz Curve and Gini Index

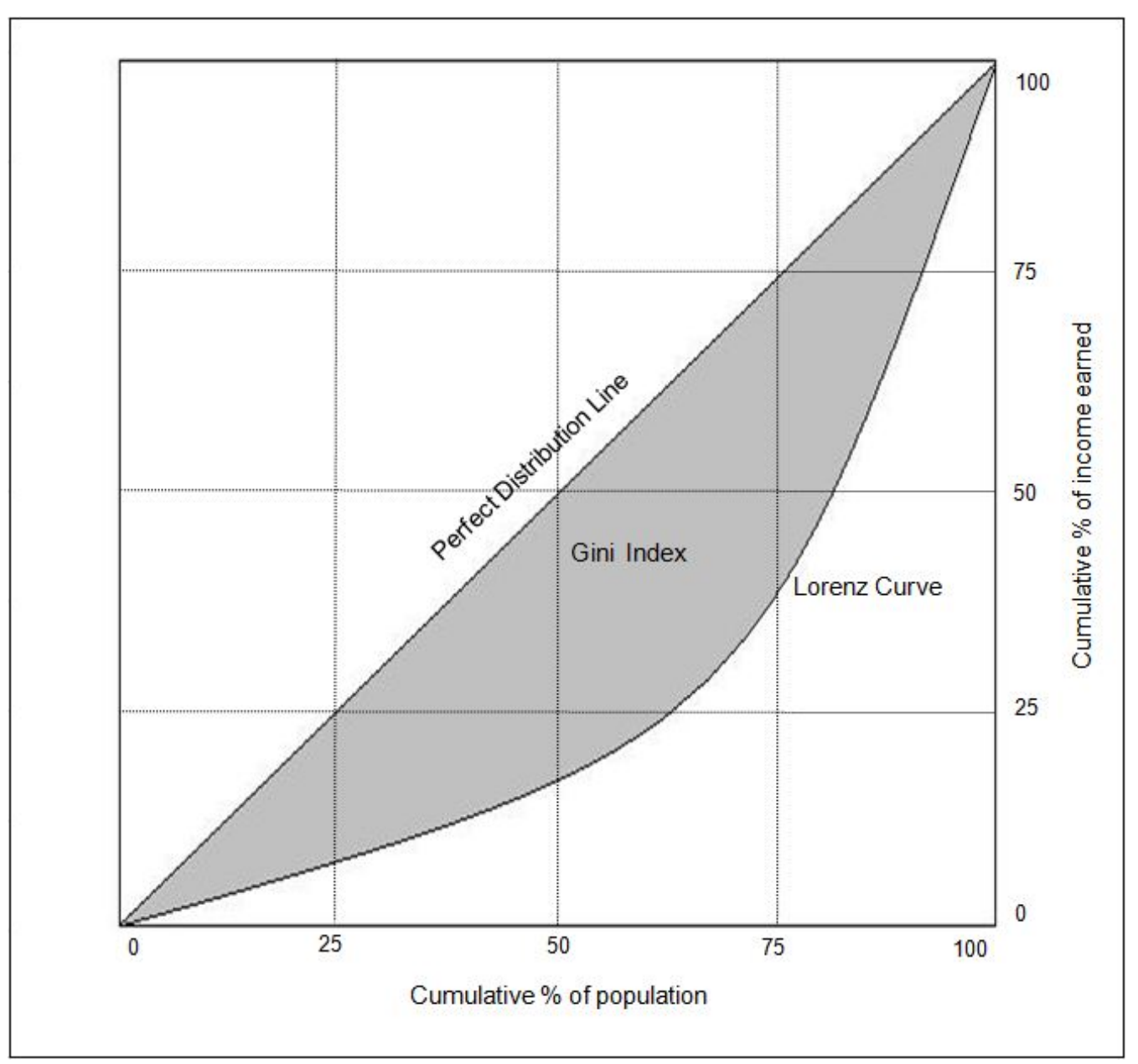


Figure 4. Cross-National Comparison of Income Inequality and Average Wealth, 2006

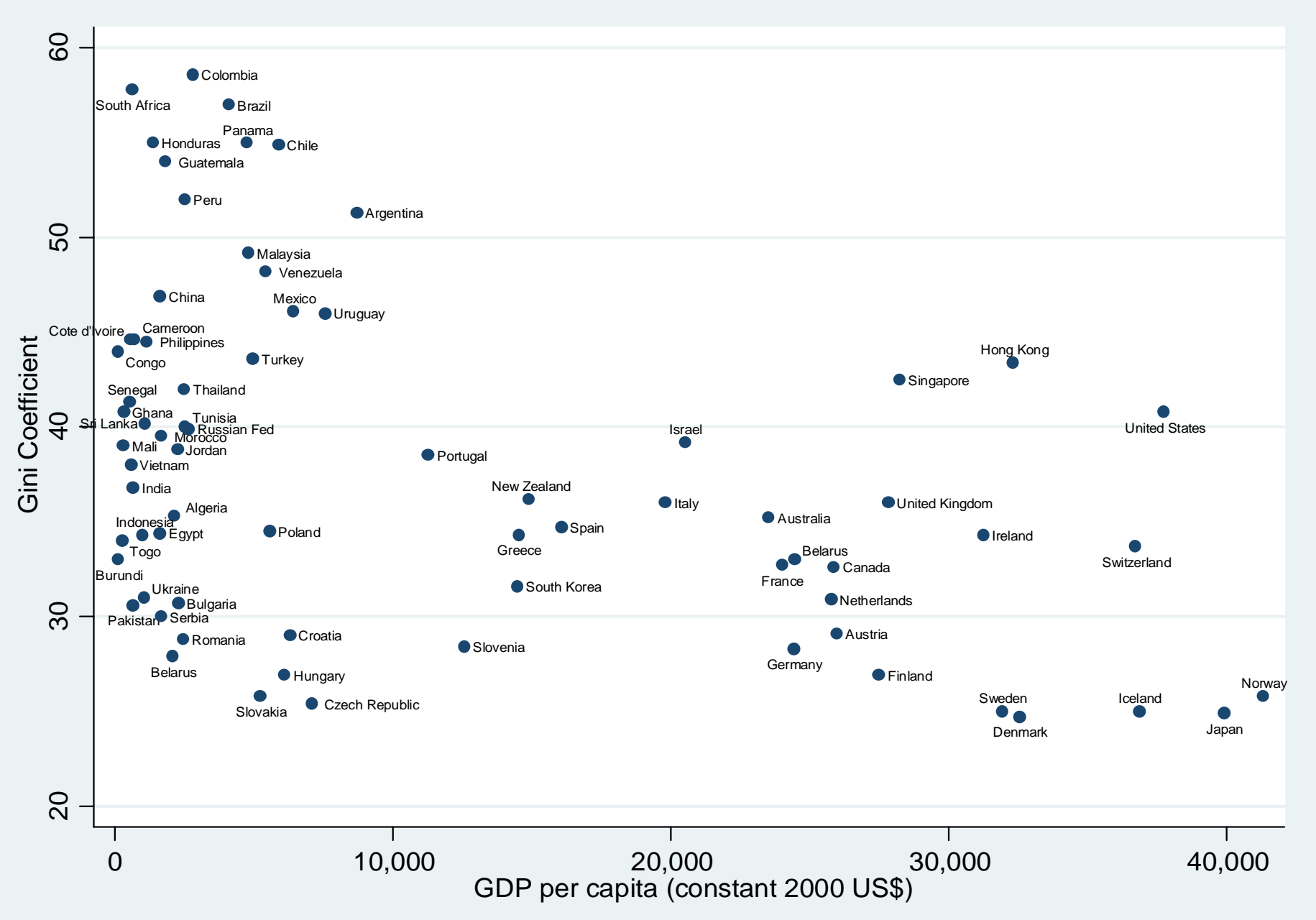


Figure 5: Comparison of Total and Domestic Employment Figures in US, 1993-2008

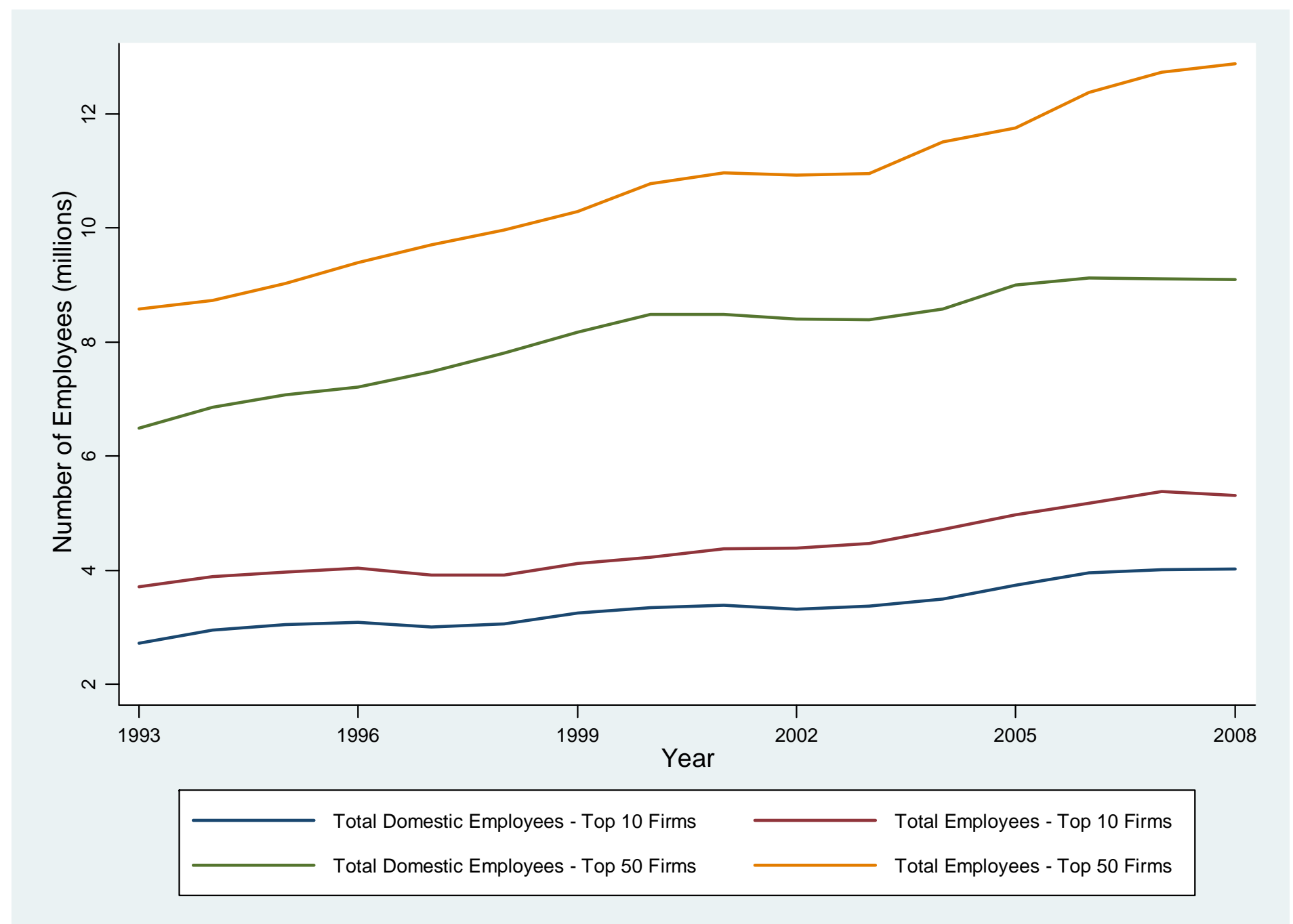


Figure 6. Three-Year Moving Average of Income Inequality and Employment Concentration in the United States, 1950 - 2006

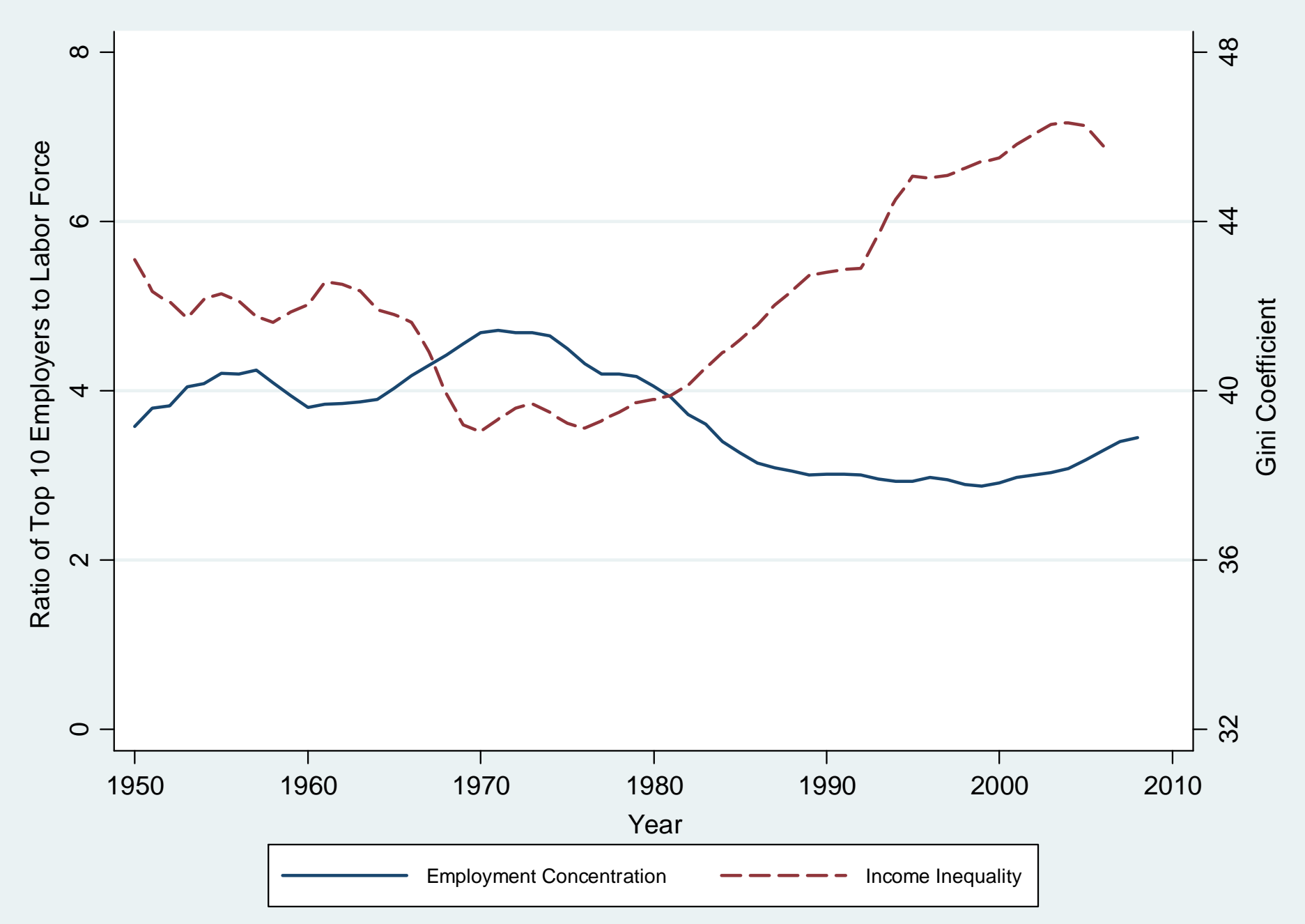


Figure 7. Income Inequality and Employment Concentration Plot in the U.S. by Year, 1950 -2006

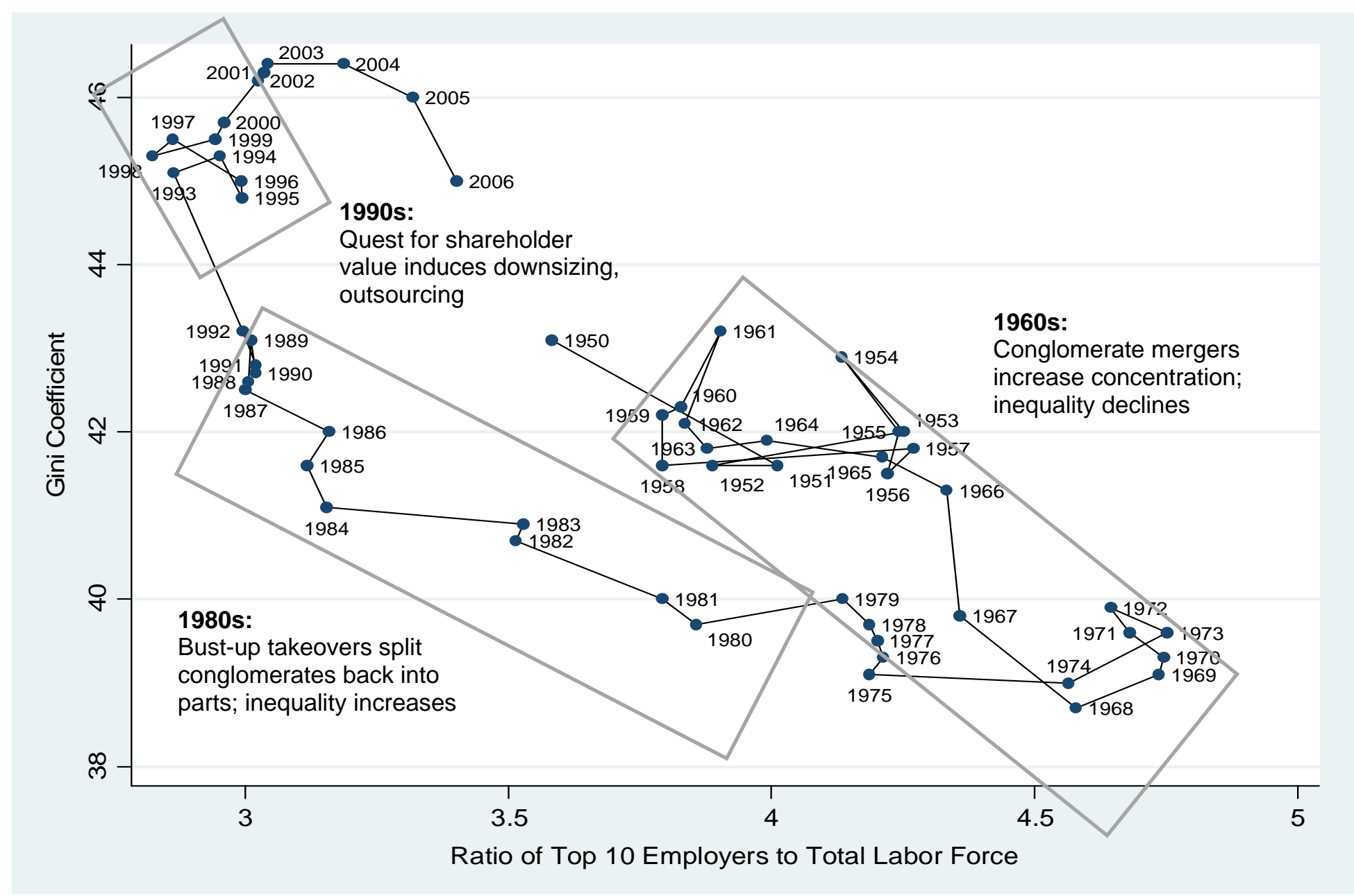


Figure 8. Three-Year Moving Average Income Inequality and Union Density in the United States, 1950 - 2006

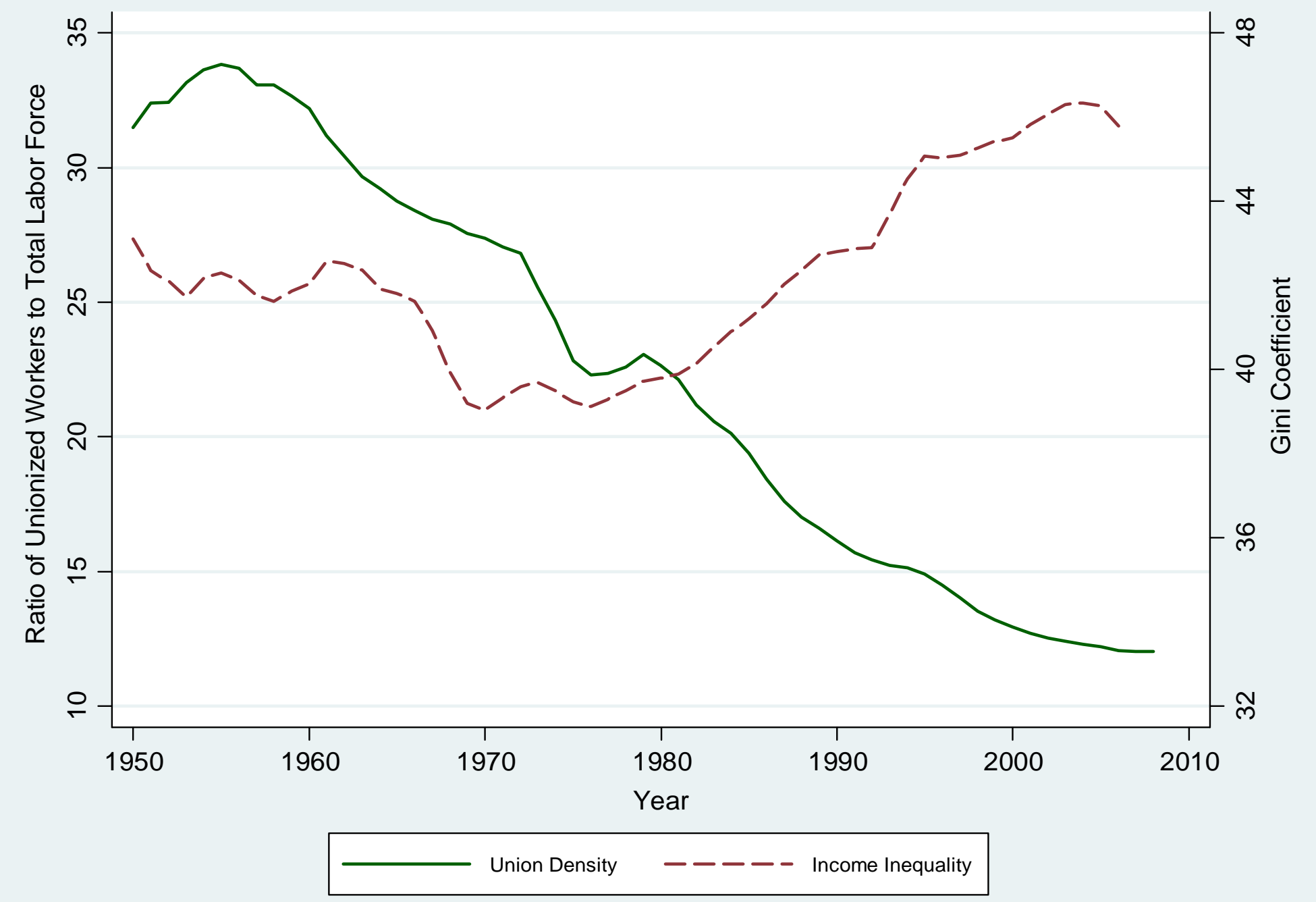


Figure 9. Cross-National Comparison of Income Inequality and Employment Concentration, 2006

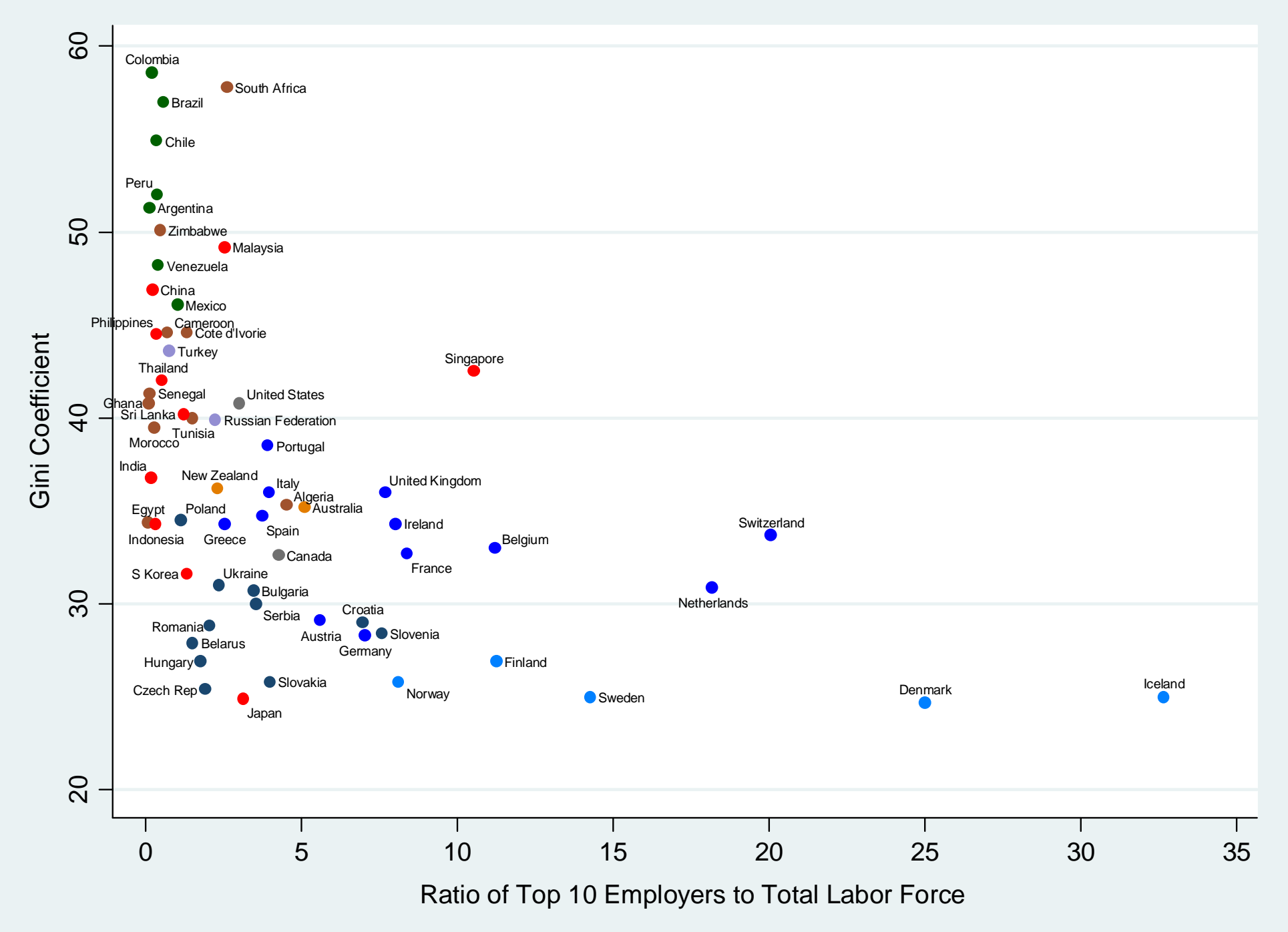

